\title{
PENGEMBANGAN PERANGKAT PEMBELAJARAN FISIKA MODEL PENEMUAN TERBIMBING UNTUK MELATIHKAN KETERAMPILAN PROSES SAINS PADA MATERI POKOK SUHU DAN KALOR
}

\author{
Sri Martini ${ }^{1)}$ \\ ZA Imam Supardi ${ }^{2)}$ \\ Rudiana Agustini ${ }^{2}$
}

1) Mahasiswa Prodi Pendidikan Sains Program Pascasarjana Unesa

2) Dosen Prodi Pendidikan Sains Program Pascasarjana Unesa

e-mail:martiniyani@gmail.com

\begin{abstract}
The research consist of two steps. The first step discusses about the development of physics teaching and learning materials of guided discovery model, in order to practice science process skills by adapting 4-D model. The second focuses on the implementation of the physics learning set developed by using one group pretest-posttest research design.It is done to 32 students on X C of SMAN 1 Pamekasan 2012/2013 which concern on the main topic Temperature and Heat, by four observers and without replication. The developed materials set is lesson plan (RPP), worksheets (LKS), student's book, and form of assesment validated by three experts (validator). Those are categorized "good" and "visiable" to be used in the teaching-learning process. The result of this research is analized descriptively, namely: (1) the lesson plan (RPP) implementation is categorized "good" with implemented persentage $92,25 \%$, (2) the most dominant of students learning activity is doing discovery activity to practice the students science process skills that is 32,91\%, (3) the improvement of students science process skills through the result of 8 aspects observation classically, (4) the result of students learning on THB product, science process skills, and psycomotoric individually have improvement and it's classically categorized "complete", (5) students response positively and anthusiastically toward guided learning discovery in order to practice science process skills, and (6) the obstacles found on this field, students are not familiar with guided learning discovery model and doing scientific research to practice science process skill, so that the use of time often is not suitable with the lesson plan (RPP) due to the new discoveries that must be explanned to the students.
\end{abstract}

Key words: Guided discovery; science process skills; temperature and heat

\begin{abstract}
Abstrak: Penelitian ini dilaksanakan dalam dua tahap. Tahap pertama mengembangkan perangkat pembelajaran fisika model penemuan terbimbing untuk melatihkan keterampilan proses sains dengan mengadaptasi model 4-D. Tahap kedua adalah implementasi perangkat pembelajaran fisika yang dikembangkan dengan menggunakan desain penelitian one group pretest-posttest design. Peneltian ini dilakukan di SMAN 1 Pamekasan dengam sampel 32 orang siswa kelas X C tahun pelajaran 2012/2013 pada materi pokok suhu dan kalor, dengan empat orang pengamat tanpa replikasi. Perangkat yang dikembangkan berupa RPP, LKS, Buku Ajar Siswa, dan Lembar Penilaian telah divalidasi oleh tiga pakar (validator) dengan kategori baik dan layak digunakan dalam pembelajaran. Hasil yang diperoleh dalam penelitian ini dianalisis secara deskriptif diantaranya, (1) keterlaksanaan RPP dikategorikan baik, dengan persentase keterlaksanaan 92,25\%, (2) aktivitas siswa dalam pembelajaran yang paling dominan adalah melakukan kegiatan penemuan untuk melatihkan keterampilan proses sains siswa sebesar 32,91\%, (3) hasil pengamatan 8 aspek keterampilan proses sains siswa secara klasikal meningkat, (4) hasil belajar siswa pada THB produk, keterampilan proses sains maupun psikomotor secara individu meningkat dan secara klasikal dikategorikan tuntas, (5) respon siswa positif dan antusias terhadap pembelajaran penemuan terbimbing untuk melatihkan keterampilan proses sains siswa, dan (6) kendala/hambatan yang ditemukan di lapangan, siswa masih belum terbiasa dengan pembelajaran penemuan terbimbing, dan melakukan penyelidikan ilmiah untuk melatihkan keterampilan proses sains, sehingga penggunaan waktu kadang kurang sesuai dengan RPP karena banyak hal baru yang perlu dijelaskan pada siswa.
\end{abstract}

Kata-kata Kunci: Penemuan terbimbing, keterampilan proses sains, suhu dan kalor

\section{Pendahuluan}

Kemajuan suatu bangsa ditandai dengan meningkatnya kualitas kehidupan serta meningkatnya harkat dan martabat bangsa tersebut. Hal ini dapat dicapai dengan penataan pendidikan yang baik. Peran pendidikan sangat penting untuk menciptakan kehidupan yang cerdas, damai, terbuka dan demokratis, oleh karena itu pembaharuan pendidikan harus selalu dilakukan sehingga pendidikan adaptif terhadap perkembangan zaman.
Pembaharuan pendidikan yang diinginkan adalah tersusunnya suatu kurikulum yang menekankan prinsip kegiatan pembelajaran berpusat pada siswa, belajar dengan melakukan, mengembangkan keterampilan memecahkan masalah, mengembangkan kreatifitas, kemampuan menggunakan IPTEK, serta perpaduan kompetisi, kerjasama, dan solidaritas (Depiknas, 2007). Berdasarkan uraian di atas, kegiatan pembelajaran harus berpusat pada siswa, dengan memberikan kesempatan kepada siswa untuk menggunakan strategi-strategi 
mereka sendiri sehingga memiliki kemampuan memperoleh dan membangun pengetahuan di dalam benaknya sendiri, dan mengembangkan potensi dirinya sesuai dengan bakat, minat, dan perkembangan fisik serta mentalnya.

Demikian juga dalam pembelajaran IPA, senantiasa lebih diarahkan pada kegiatan-kegiatan yang dapat mendorong siswa untuk belajar aktif, baik secara mental, isik maupun sosial. Fisika adalah cabang sains, oleh karena itu hakekat fisika dapat ditinjau dan dipahami dari hakikat sains. Sains merupakan kesatuan produk, proses dan sikap sehingga tujuan pembelajaran fisika harus mengacu pada tiga aspek esensial tersebut.

Kenyataan di lapangan menunjukkan bahwa para guru cenderung masih menggunakan cara konvensional dalam mengajar fisika. Penyajian materi juga kurang mengajak siswa untuk berfikir dalam proses mencari tahu fenomena alam yang bekaitan dengan kenyataan seharihari. Hasil penelitian TIMSS (Trends in International Mathematic and Science Study), yaitu studi empat tahunan yang dilakukan oleh IEA (International Association for the Evaluation of Educational Achievment) menunjukkan bahwa:

Rata-rata skor prestasi sains siswa Indonesia pada TIMSS tahun 1999, 2003, dan 2007 secara berurutan adalah 435, 430, dan 433. Dengan skor tersebut siswa Indonesia menempati peringkat 32 dari 38 negara (tahun 1999), peringkat 37 dari 46 negara (tahun 2003), dan peringkat 35 dari 49 negara (tahun 2007). Rata-rata skor siswa Indonesia pada TIMSS tahun 2007 di bawah skor rata-rata yaitu 500, dan hanya mencapai Low Internatonal Benchmark (Efendi, 2010:385)

Efendi (2010) menjelaskan bahwa soal-soal yang diujikan dalam TIMSS berada dalam cakupan tiga domain kognitif (knowing, applying, reasoning) yaitu pengetahuan, aplikasi, dan penalaran dalam kehidupan nyata. Hasil penelitian tersebut menunjukkan bahwa siswa Indonesia hanya mampu mengenali sejumlah fakta dasar tetapi belum mampu mengkomunikasikan dan mengaitkan berbagai topik sains, apalagi menerapkan konsep-konsep yang kompleks dan abstrak.

Berkenaan dengan kenyataan di atas, pembelajaran dengan melatihkan keterampilan proses sains diharapkan dapat menjadi pembelajaran alternatif. Pembelajaran ini lebih menekankan pada proses pencarian pengetahuan dari pada transfer pengetahuan. Siswa dipandang sebagai suyjek belajar yang perlu dilibatkan secara aktif dalam proses pembelajaran, guru hanyalah seorang fasilitator yang membimbing dan mengkoordinasikan kegiatan belajar siswa. Mengurangi bantuan tersebut dan memberikan ksempatan kepada anak tersebut untuk mengambil alih tanggung jawab yang semakin besar setelah anak dapat melakukannya

\section{METODE PENELITIAN}

Penelitian ini merupakan penelitian pengembangan. Subjek penelitian ini adalah siswa kelas X C SMAN 1 Pamekasan dengan sampel penelitian berjumlah 32 siswa, dan tanpa replikasi. Penelitian dilaksanakan pada tanggal 8 Oktober 2012 sampai dengan 25 Oktober 2012. Lokasi Penelitian di SMA Negeri 1 Pamekasan, J1 Pramuka No. 2 Pamekasan.

Penelitian ini meliputi dua tahap yaitu, 1) tahap pengembangan perangkat pembelajaran fisika model penemuan terbimbing untuk melatihkan keterampilan proses sains siswa dan 2) tahap implementasi perangkat pembelajaran yang dikembangkan. Pengembangan perangkat pembelajaran pada penelitian ini mengadaptasi model 4-D (Four-D) menurut Thiagarajan dan Semmel, (1975) meliputi: pendefinisian (define), perancangan (design), pengembangan (develop), dan penyebaran (disseminate). Perangkat pembelajaran yang dikembangkan berupa RPP, LKS, Buku Ajar Siswa, dan Lembar Penilaian kognitif produk, keterampilan proses sains dan psikomotor. Selanjutnya perangkat pembeljaran tersebut divalidasi oleh 3 pakar di bidang pengembangan kurikulum, bidang evaluasi, dan bidang pendidikan IPA. Tahap pengembangan dilanjutkan dengan memperbaiki perangkat pembelajaran sesuai saran dari validator dan dilanjutkan dengan ujicoba terbatas untuk mengetahui validitas, reliabiitas, dan sensitivitas perangkat pembelajaran tersebut.

Tahap selanjutnya yaitu tahap implementasi perangkat pembelajaran pada kelas sebenarnya. Rancangan penelitian yang digunakan adalah One Group Pretest-Posttest Design (Prabowo, 2011) polanya sebagai berikut:

$$
\mathrm{U} 1 \longrightarrow \mathrm{L} \longrightarrow \mathrm{U} 2
$$

\section{Keterangan:}

$\mathrm{U}_{1}=$ Memberikan uji awal, untuk merekam data tentang kemampuan awal siswa terhadap materi suhu dan kalor.

$\mathrm{L}=$ Memberikan perlakuan pada siswa, yaitu dengan menggunakan perangkat pembelajaran dengan model penemuan terbimbing untuk melatihkan keterampilan proses sains siswa.

$\mathrm{U}_{2}=$ Memberikan uji akhir $\mathrm{O}_{2}$, untuk merekam data tentang penguasaan siswa terhadap materi suhu dan kalor setelah diberikan perlakuan.

Selama perlakuan berlangsung juga akan dilakukan observasi keterlaksanaan pembelajaran, aktivitas siswa, keteramplan proses sains siswa, respon siswa dan hambatan dalam pembelajaran yang dlakukan oleh empat pengamat..

Instrumen dari penelitian ini terdiri dari lembar validasi, lembar pengamatan keterlaksanaan proses pembelajaran, lembar pengamatan aktivitas siswa, lembar 
pengamatan keterampilan proses sains siswa, angket respon siswa, lembar tingkat keterbacaan serta kesulitan LKS dan Buku Ajar Siswa, dan Tes Hasil Belajar kognitif produk, keterampilan proses sains, dan psikomotor.. Pengumpulan data menggunakan metode observasi, tes hasil belajar dan angket. Teknik analisa data validasi perangkat pembelajaran, keterlaksanaan pembelajaran, aktivitas siswa, dan respon siswa menggunakan analisis data deskriptif kualitatif. Tes Hasil Belajar siswa dianalisis dengan deskriptif kuantitatif.

\section{Hasil Penelitian dan Pembahasan}

Hasil penilaian validator terhadap perangkat pembelajaran yang telah dikembangkan menunjukkan bahwa kualitas RPP, LKS, dan Buku Ajar Siswa, layak untuk diimplementasikan dalam pembelajaran fisika materi suhu dan kalor dengan kualitas sangat baik dari segi format, bahasa dan isi. Tes Hasil Belajar kognitif produk yang dikembangkan berupa 20 soal pilihan ganda memiliki koefisien reliabilitas yang tinggi yaitu 0,93, reliabilitas Tes Hasil Belajar keterampilan proses sains siswa sebesar 0,88, dan reliabilitas Tes Hasil Belajar psikomotor sebesar 0,90. Persentase rata-rata tingkat keterbacaan Buku Ajar Siswa dan LKS berturut-turut $77,3 \%$ dan $78,32 \%$, sehingga kategori tingkat keterbacaan adalah materi tepat untuk pembelajaran. Persentase rata-rata tingkat kesulitan Buku Ajar Siswa sebesar $1,81 \%$, dan persentase rata-rata LKS sebesar $6,80 \%$, sehingga dikategorikan kecil atau sangat mudah.

Aspek yang diamati pada pelaksanaan pembelajaran meliputi lima kegiatan utama yaitu kegiatan pendahuluan, kegiatan inti, kegiata akhir, pengelolaan waktu dan gambaran suasana kelas/antusiasme. Hasil pengamatan terhadap pelaksanaan pembelajaran memiliki persentase keterlaksanaan pada masing-masng pertemuan adalah, pertemuan $1=98 \%$, pertemuan $2=$ $99 \%$, pertemuan $3=100 \%$, dan pertemuan $4=100 \%$. seperti yang disajikan pada grafik berikut ini.

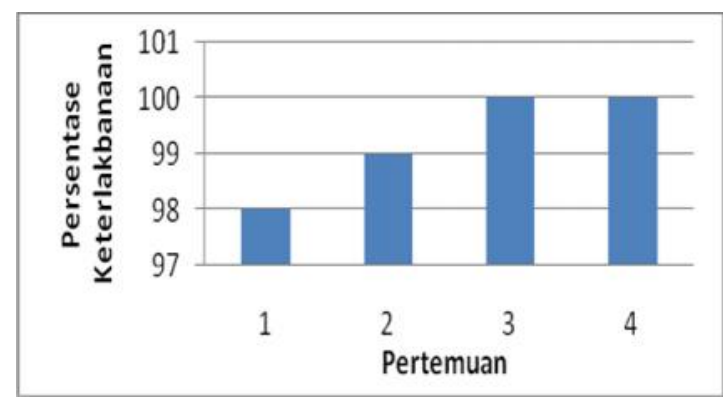

Grafik 1. Persentase keterlaksanaan RPP

Persentase keterlaksanaan RPP rata-rata sebesar $99,25 \%$, yang berarti bahwa pembelajaran dilaksanakan dan berjalan dengan baik sesuai dengan sintaks RPP yang dikembangkan. Guru mampu mengoperasikan perangkat pembelajaran dari kegiatan pendahuluan sampai kegiatan akhir dan membuat siswa antusias dalam mengikuti pembelajaran. Sedangkan koefisien reliabilitas intsrumen pada masing-masing pertemuan adalah, pertemuan $1=$ $91 \%$, pertemuan $2=95 \%$, pertemuan $3=100 \%$, dan pertemuan $4=100 \%$. Instrumen ini dikategorikan baik dan dapat digunakan dalam kegiatan pengamatan karena memiliki koefisien reliabilitas rata-rata 98,80\%. Lembar pengamatan dikatakan baik jika koefisien reliabilitasnya $\geq 0,70$ atau $70 \%$ (Borich, 1994).

Hasil pengamatan terhadap aktvitas siswa yang meliputi membaca/mencari informasi yang relevan, mendengarkan/memperhatikan penjelasan guru, bertanya kepada guru, mencatat, mendiskusikan tugas, melakukan pengamatan, merencanakan dan melaksanakan percobaan/kegiatan penemuan untuk melatihkan keterampilan proses sains, mengkomunikasikan hasil percobaan, membuat simpulan dan rangkuman, mengevaluasi langkah-langkah kegiatan penemuan yang telah dilakukan, mengerjakan evaluasi/tes, dan perilaku yang tidak relevan, dinyatakan dengan teknik percentage of agreement, dan dapat disajikan dalam grafik berikut ini.

Berdasarkan grafik 2 diperoleh informasi bahwa dari sebelas aspek yang diamati, aspek no 6 yaitu melakukan pengamatan, merencanakan dan melaksanakan percobaan/kegiatan penemuan untuk melatihkan keterampilan proses sains merupakan aspek yang paling dominan karena memiliki persentase terbesar yaitu sebesar 32,91\%. Hal ini menunjukkan bahwa siswa antusias untuk melakukan kegiatan penemuan. Instrumen yang digunakan memiliki reliablitas masing-masing untuk pertemuan $1=94,69 \%$, pertemuan $2=95,48 \%$, pertemuan $3=95,83 \%$, dan pertemuan $4=94,03 \%$. Berdasarkan reliabilitas keempat pertemuan tersebut diperoleh reliablitas rata-rata sebesar 95,01\%, sehingga instrumen tersebut dikatakan reliabel. Instrumen dikatakan reliabel apabila reliabilitasnya $\geq 0,75(75 \%)$. (Borich, 1994)

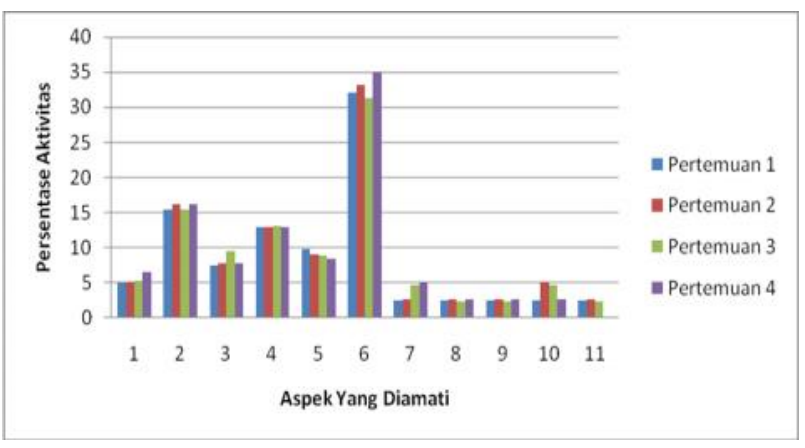

Grafik 2. Pengamatan Aktivitas Siswa

Berdasarkan pemaparan di atas, nampak bahwa aktivitas siswa selama proses pembelajaran 
menggambarkan aktivitas siswa yang sesuai dengan tahap-tahap pembelajaran model penemuan terbimbing untuk melatihkan keterampilan proses sains siswa. Keterlaksanaan pembelajaran penemuan sebagaimana yang tertuang dalam RPP akan meningkatkan aktivitas siswa selama proses pembelajaran. Hal ini sesuai dengan Piaget dan Dewey (dalam Carin, 1993:94) menyatakan bahwa; "We learn by doing and reflecting are what we do". Menurut Dewey, kita belajar dengan terlibat aktif dalam pembelajaran, dan melakukan refleksi terhadap apa yang kita lakukan.

Pembelajaran penemuan merupakan pengajaran yang mendorong siswa untuk menemukan prinsip-prinsip untuk diri mereka sendiri, sehingga mereka termotivasi untuk belajar sesuai dengan pernyataan Carin (1993:93) "Your student will become more self motivated where their approach learning by discovering something themselves, rather than only learning about it". Siswa akan lebih termotivasi jika di dalam belajar mereka menemukan sesuatu oleh mereka sendiri jika dibandingkan mereka hanya mendengarkan materi pembelajaran. Selama proses pembelajaran siswa diberi kebebasan untuk menemukan konsep/prinsip oleh diri mereka sendiri, dan mendapatkan bimbingan agar pembentukan konsep menjadi lebih bermakna.

Keterampilan proses sains siswa yang diamati pada penelitian ini meliputi kegiatan (1) merumuskan masalah, (2) merumuskan hipotesis, (3) mengidentifikasi variabel, (4) definisi operasional variabel, (5) merancang prosedur percobaan, (6) teknik pengambilan data, (7) menganalisa data, dan (8) membuat simpulan. Pengamatan ini dilakukan terhadap lima kelompok siswa yang masing masing kelompok terdiri dari enam orang siswa. Hasil rekapitulasi data pengamatan dianalisis dan disajikan dalam tabel berikut ini.

Tabel 1. Keterampilan Proses Sains Siswa Tiap Kelompok

\begin{tabular}{|c|c|c|c|c|c|c|c|c|}
\hline \multirow{2}{*}{$\begin{array}{c}\text { Ke } \\
\text { lom } \\
\text { pok }\end{array}$} & \multicolumn{2}{|c|}{ Pertemuan } \\
\cline { 2 - 11 } & $\begin{array}{c}\text { Jml } \\
\text { Skor }\end{array}$ & $\begin{array}{c}\text { Ni } \\
\text { lai }\end{array}$ & $\begin{array}{c}\text { Jml } \\
\text { Skor }\end{array}$ & $\begin{array}{c}\text { Ni } \\
\text { lai }\end{array}$ & $\begin{array}{c}\text { Jml } \\
\text { Skor }\end{array}$ & $\begin{array}{c}\text { Ni } \\
\text { lai }\end{array}$ & $\begin{array}{c}\text { Jml } \\
\text { Skor }\end{array}$ & $\begin{array}{c}\text { Ni } \\
\text { lai }\end{array}$ \\
\hline I & 7 & 22 & 14 & 44 & 20 & 63 & 25 & 78 \\
\hline II & 6 & 19 & 14 & 44 & 18 & 56 & 26 & 81 \\
\hline III & 8 & 25 & 17 & 53 & 23 & 72 & 29 & 91 \\
\hline IV & 6 & 19 & 15 & 47 & 21 & 66 & 25 & 78 \\
\hline V & 7 & 22 & 18 & 56 & 23 & 72 & 28 & 88 \\
\hline
\end{tabular}

Tabel 1 menunjukkan bahwa nilai keterampilan proses sains tiap kelompok pada pertemuan 1 sangat rendah, namun setelah diberikan bimbingan, kemudian meningkat di pertemuan 2 dan 3 . Pada pertemuan 4 keterampilan proses sains siswa sudah baik. Hasil pengamatan keterampilan proses sains secara klasikal dapat disajikan pada grafik 3 berikut ini.

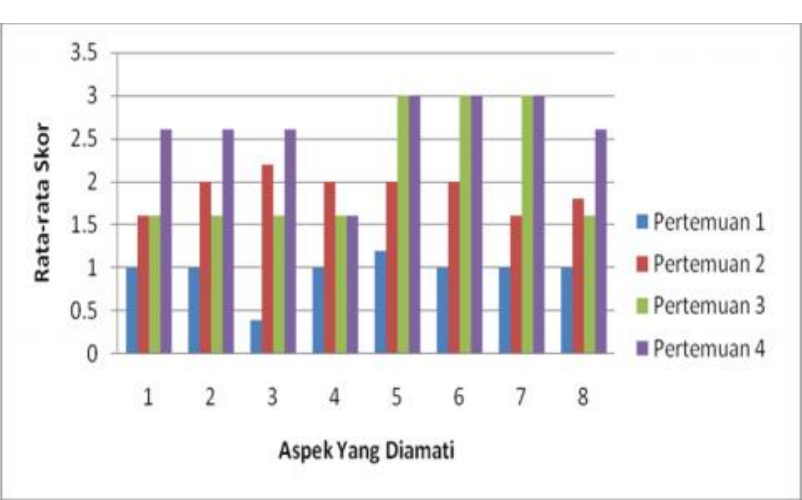

Grafik 3. Keterampilan Proses Sains Siswa

Berdasarkan grafik 3 diperoleh informasi bahwa keterampilan proses sains siswa tiap aspek secara klasikal pada pertemuan 1 sangat rendah. Pada pertemuan 2 dan 3 mulai meningkat dengan adanya bimbingan guru. Pada pertemuan 4, siswa telah terlatih dengan keterampilan proses sains untuk melakukan kegiatan penemuan. Aspek yang memiliki skor paling rendah adalah merumuskan definisi operasional variabel.

Tes awal (pretest) diberikan sebelum implementasi perangkat pembelajaran dilaksanakan, dengan tujuan untuk mengetahui pengetahuan awal siswa sebelum mendapat perlakuan pembelajaran dari peneliti. Pada akhir proses pembelajaran, tes akhir (posttest) dilakukan dengan tujuan untuk mengetahui pengetahuan siswa setelah mendapat perlakuan penerapan pembelajaran penemuan terbimbing yang telah dikembangkan oleh peneliti. Tes Hasil Belajar kognitif produk tentang suhu dan kalor yang dikembangkan peneliti berupa 20 soal pilihan ganda, dapat dikatakan peka/sensitif terhadap efek-efek pembelajaran yang telah dilaksanakan. Hal tersebut dapat dilihat dari sensitivitas keseluruhan butir soal memiliki tingkat sensitivitas $\geq 0,30$.

Berdasarkan analisis data hasil uji akhir diperoleh informasi bahwa dari 20 soal pilihan ganda (multiple choice), soal nomor 14 memiliki indeks sensitivitas 0,66 , dan nomor 17 memiliki indeks sensitivitas 0,63 dan sekaligus sebagai indeks sensitivtas terendah, dimana kedua soal tersebut membahas tentang materi perubahan wujud. Penyebab kecilnya indeks sensitivitas ini karena setelah diterapkan pembelajaran model penemuan terbimbing untuk melatihkan keterampilan proses, proporsi jawaban yang diperoleh siswa untuk nomor 14 dan 17 masih dibawah KKM $(0,76)$. Siswa kesulitan pada materi perubahan wujud karena aplikasi soal pada materi ini cukup kompleks dan siswa kesulitan dalam menganalisis grafik, namun demikian soal ini dianggap masih layak dan peka/sensitif terhadap efek-efek pembelajaran yang dilaksanakan.

Ketuntasan belajar siswa mencapai 90,63\% dengan nilai rata-rata 80,41 dan nilai rata-rata peningkatan (gain 
score) 79,28. Dengan demikian, dapat dikatakan bahwa hasil belajar kognitif produk secara klasikal adalah tuntas karena memiliki ketuntasan $\geq 85 \%$.

Berdasarkan hasil telaah jawaban siswa diperoleh informasi bahwa siswa-siswa yang tidak tuntas mengalami kesulitan pada indikator 17, yang berbunyi "Siswa dapat menganalisa grafik fasa perubahan air dari es hingga menjadi uap". Dengan melihat jawabanjawaban siswa, ditemukan kesamaan yang dihadapi siswa yaitu kesulitan dalam menganalisa grafik fase perubahan air dari es hingga uap. Selain itu siswa kesulitan dalam menerapkan dua persamaan atau lebih dalam satu permasalahan. Oleh karena itu siswa perlu diberi latihan soal-soal yang variatif dalam jumlah yang cukup sehingga aktivitas berfikir siswa pada tahap penerapan konsep meningkat. Peningkatan aktivitas berfikir ini tentu akan berdampak pada kemampuan kognitif siswa. Jika dikaitkan dengan teori pembelajaran kognitif Piaget, kesulitan yang dihadapi siswa ini menunjukkan bahwa combirational reasoning siswa masih lemah. Combirational reasoning berkaitan dengan kemampuan siswa untuk menyelesaikan masalah-masalah yang melibatkan banyak variabel dalam satu waktu. Jika diperhatikan, usia subyek penelitian (siswa kelas X) tahap berfikir mereka sudah mencapai tahap berfikir operasi formal. Piaget (dalam Wardsworth, 1984) menyebutkan bahwa konten pemikiran formal adalah propositional, or combirational operation dan formal operational scheme. Siswa pada periode terakhir tahap perkembangan kognitif Piaget yaitu tahap operasi formal, seharusnya telah mampu berpikir secara abstrak, menalar secara logis, dan menarik kesimpulan dari informasi kompleks. Rendahnya combirational reasoning siswa ini diduga karena selama ini siswa jarang diberikan soal-soal pada dimensi pengetahuan konseptual level proses kognitif menganalisis.

Pembelajaran model penemuan terbimbing merupakan pengajaran yang mendorong siswa untuk menemukan prinsip-prinsip dan konsep untuk diri mereka sendiri, sehingga potensi intelektualnya meningkat, hal ni sesuai dengan pernyataan Bruner dalam Carin (1993:93) bahwa: "an individual learn and develops his or her mind only by using it", artinya potensi intelektual seseorang akan berkembang hanya jika ia menggunakan potensi tersebut. Dengan demikian, anak akan belajar dengan baik jika pikiran mereka bekeja terhadap apa yang dia pelajari, dan ini hanya dapat terjadi melalui mendengar, membaca, melihat, berbuat dan berfikir. Semakin banyak aktivitas berfikir yang dilakukan oleh seseorang, maka potensi intelektualnya akan semakin tinggi. Potensi intelektual secara langsung berkaitan dengan tingkat pemahaman mereka terhadap materi sains.
Hasil Belajar keterampilan proses sains yang diukur pada penelitian ini meliputi merumuskan masalah, merumuskan hipotesis, identifikasi variabel, definisi operasional variabel, merancang prosedur percobaan, mengambil data percobaan, menganalisis data percobaan, dan membuat simpulan.THB keterampilan proses sains yang dikembangkan peneliti berupa 8 soal uraian, dapat dikatakan peka/sensitif terhadap efek-efek pembelajaran yang telah dilaksanakan. Hal tersebut dapat dilihat dari sensitivitas keseluruhan butir soal memiliki tingkat sensitivitas $\geq 0,30$. Ketuntasan belajar siswa mencapai $100 \%$ dengan nilai rata-rata 84,41 dan nilai rata-rata peningkatan (gain score) 76,03. Dengan demikian, dapat dikatakan bahwa hasil belajar keterampilan proses sains siswa secara klasikal adalah tuntas karena memiliki ketuntasan $\geq 85 \%$.

Berdasarkan hasil telaah jawaban siswa pada tes keterampilan proses sains, siswa merasa kesulitan mendefinisikan operasional variabel. Kesulitan siswa dalam merumuskan definisi operasional variabel akan berdampak pada ketidakmampuan siswa untuk merancang prosedur percobaan, karena definisi operasional variabel berisi tentang cara variabel-variabel diukur, dan dengan apa variabel-variabel tersebut diukur. Hal ni juga disebabkan karena pada pembelajaran model penemuan terbimbing, prosedur percobaan telah disajikan dalam LKS, dimana siswa hanya membaca, memahami, dan menerapkan prosedur yang telah disajikan, sehingga aktivitas berfikir siswa hanya berada pada level proses kognitif menerapkan $\left(\mathrm{C}_{3}\right)$ kategori executing, sedangkan merancang prosedur percobaan merupakan aktivitas berfikir yang berada pada level kognitif menciptakan $\left(\mathrm{C}_{6}\right)$ kategori planing. Oleh karena itu, untuk indikator yang memiliki level proses kognitif tinggi, guru perlu memberikan scaffolding yang cukup dan merata kepada seluruh siswa, sehingga siswa maksimum dalam menuntaskan indikator tersebut.

Hasil belajar psikomotor yang diukur dalam penelitian ini meliputi beberapa aspek yakni, menggunakan termometer, (2) menggunakan gelas ukur, (3), menggunakan stop watch, (4) menggunakan neraca, (5) menggunakan kalorimeter, dan (6) merakit alat percobaan. Hasil yang diperoleh menunjukkan bahwa hasil belajar psikomotor dari enam aspek yang dinilai, memiliki rata-rata nilai 82,19 , dan secara klasikal dapat dikatakan tuntas karena memiliki persentase ketuntasan 90,63\%. Secara klasikal dikatakan tuntas jika jumlah siswa yang tuntas secara individu $\geq 85 \%$.

Siswa memberikan respon positif, terhadap pembelajaran model penemuan terbimbing untuk melatihkan keterampilan proses sains siswa. Sebanyak $86,46 \%$ siswa cukup tertarik dan sangat antusias terhadap pembelajaran model penemuan terbimbing.Sebanyak $56,25 \% \%$ siswa sangat minat bahwa pembelajaran 
dengan berorientasi pada penemuan terbimbing untuk melatihkan keterampilan proses sains diterapkan pada pokok bahasan selanjutnya. Sebanyak 62,50\% siswa sangat minat bahwa metode pembelajaran penemuan terbimbing dapat diterapkan pada mata pelajaran lain yang serumpun dengan fisika,.

Respon positif dan antusias merupakan kontribusi yang besar bagi motivasi belajar siswa. Siswa akan lebih termotivasi jika di dalam belajar mereka menemukan sesuatu oleh mereka sendiri jika dibandingkan mereka hanya mendengarkan materi pembelajaran, sesuai dengan pernyataan Carin (1993:93) bahwa: "Your student will become more self motivated where their approach learning by discovering something themselves, rather than only learning about it".

Dalam penelitian ini ditemukan beberapa kendala/hambatan di lapangan yang dapat mempengaruhi kualitas proses belajar mengajar yang sedang dilaksanakan. Kendala utama yang ditemukan di lapangan adalah siswa merasa baru dan belum terbiasa dengan pembelajaran model penemuan terbimbing dalam melathkan keterampilan proses sains, sehingga penggunaan waktu kadang kurang sesuai dengan RPP karena banyak hal baru yang perlu dijelaskan pada siswa. Solusi dari permasalahan tersebut adalah memberikan penjelasan dan petunjuk teknis pelaksanaan kegiatan penemuan di luar jam pelajaram.

\section{SIMPULAN}

Berdasarkan hasil penelitian, analisis data, dan pembahasan, didapatkan beberapa temuan yang menjadi simpulan hasil penelitian bahwa perangkat pembelajaran yang telah dikembangkan secara keseluruhan dapat dikatakan layak dan dapat digunakan dalam pembelajaran yang sesungguhnya dan pembelajaran penemuan terbimbing dinyatakan dapat meningkatkan hasil belajar siswa dan dapat melatihkan keterampilan proses sains siswa.

\section{DAFTAR PUSTaka}

Abruscato, J. 1992. Teaching Children Science $3^{\text {rd }}$. Needham Heights: Allyn and Bacon.

Anderson, L.D. dan Krathwohl, D.R. 2001. A Taxonomy for Learning, Teaching, and Assesing. Newyork. AddisonWesley Longman. Inc.

Arikunto, S. 2006. Dasar-dasar Evaluas Pendidikan. Edisi Revisi.Jakarta: Bumi Aksara.
Borich, G. D. 1994. Observation Skill for Effective Teaching. New York: Macmillan Publishing Company.

Carin, A.A. 1993. Teaching Science Through Discovery. New York: Macmillan Publishing Company.

Depdiknas, 2007. Model Kurikulum Tingkat Satuan Pendidikan. Jakarta: Badan Standar Nasional pendidikan. Jakarta: Dirjen Dikdasmen.

Dimyati, M dan Mujiono. 2002. Belajar dan Pembelajaran. Jakarta: Rineka Cipta.

Efendi, R. 2010. Kemampuan Fisika Siswa dalam TIMSS (Trends of International on Mathematic and Science Study). Prosiding Seminar Nasional Fisika 2010, ISBN: 978-979-98010-6-7. (Diakses melalui readonee@yahoo,com, pada tanggal 1 Februari 2012).

Karamustafaoglu, S. 2011. Improving the Science Process Skills Ability of Science Student Teachers Using I Diagrams. Turkey: Amasya University, Faculty of Education. (http/www.eurasianjournals.com/index.php/ejpce, diakses pada tanggal 20 Desember 2011).

Nur, M. 2008. Pengajaran Berpusat pada Siswa dan Pendekatan Konstruktivis dalam Pengajaran. Surabaya: Unesa Universty Press.

Nur, M. 2011, Modul Keterampilan-keterampilan Proses Sains. Surabaya: Unesa Pusat Sains dan Matematka Sekolah.

Prabowo. 2011. Metodologi Penelitian (Sais dan Pendidikan Sains). Surabaya: Unesa University Press.

Ratumanan, T. G. dan Laurens. 2003. Evaluasi Hasil Belajar Yang Relevan Dengan Kurikulum Berbasis Kompetensi. Surabaya: Unesa University Press.

Slavin, R. E. 1997. Educational Psychology: Theory and Pravtice Fifth Edition Massachusetts:Allyn and Bacon Publishers.

Subagyo. Y. Wiyanto. Marwoto, P. 2009. Pembelajaran Sains Dengan Pendekatan Keterampilan Proses Untuk Meningkatkan Hasil Belajar Siswa. FMPA Unnes Semarang (diakses melalui pmarwoto@yahoo.com pada tanggal 11 januari 2012).

Thiagarajan, S., Semmel, D.S. \& Semmel, M.I. 1974. Instructional Development of Training Center of Exceptional Children. Minepolish: Indiana University.

Tipler, P.A. 1991. Fisika untuk Sains dan Teknik. Jakarta: Erlangga.

Toharuddin, U. Hendrawati, S. dan Rustaman, A. 2011. Membangun Leterasi Sains Peserta Didik. Bandung: Humaniora.

Wadsworth, BJ. 1984. Piaget's Theory of Cognitive and Affctive Development. USA: Longman Inc. 